\author{
Marquette University \\ e-Publications@Marquette
}

$11-2011$

\title{
Reactivity of acyclic (pentadienyl)iron(1+) cations: Synthetic studies directed toward the frondosins
}

Do W. Lee

Marquette University

Rajesh K. Pandey

Marquette University

Sergey Lindeman

Marquette University, sergey.lindeman@marquette.edu

William Donaldson

Marquette University, william.donaldson@marquette.edu

Follow this and additional works at: https://epublications.marquette.edu/chem_fac

Part of the Organic Chemistry Commons

\section{Recommended Citation}

Lee, Do W.; Pandey, Rajesh K.; Lindeman, Sergey; and Donaldson, William, "Reactivity of acyclic (pentadienyl)iron(1+) cations: Synthetic studies directed toward the frondosins" (2011). Chemistry Faculty Research and Publications. 197.

https://epublications.marquette.edu/chem_fac/197 


\title{
Reactivity of acyclic (pentadienyl)iron(1+) cations: Synthetic studies directed toward the frondosins ${ }^{\dagger}$
}

\author{
Do W. Lee \\ Department of Chemistry, Marquette University \\ Milwaukee, WI \\ Rajesh K. Pandy \\ Department of Chemistry, Marquette University \\ Milwaukee, WI \\ Sergey Lindeman \\ Department of Chemistry, Marquette University \\ Milwaukee, WI \\ William A. Donaldson \\ Department of Chemistry, Marquette University \\ Milwaukee, WI
}

A short, 4-step route to the scaffold of frondosin A and B is reported. The [1-methoxycarbonyl-5-( $2^{\prime}, 5^{\prime}$-dimethoxyphenyl)pentadienyl] $\mathrm{Fe}(\mathrm{CO}) 3^{+}$ cation was prepared in two steps from (methyl 6-oxo-2,4hexadienoate) $\mathrm{Fe}(\mathrm{CO})_{3}$. Reaction of this cation with isopropenyl Grignard or cyclohexenyllithium reagents affords (2-alkenyl-5-aryl-1-methoxycarbonyl-3pentene-1,5-diyl) $\mathrm{Fe}(\mathrm{CO})_{3}$ along with other addition products. Oxidative decomplexation of these (pentenediyl)iron complexes, utilizing $\mathrm{CuCl}_{2}$, affords 6-aryl-3-methoxycarbonyl-1,4-cycloheptadienes via the presumed intermediacy of a cis-divinylcyclopropane.

Organic and Biomolecular Chemistry, Vol. 9, No. 22 (November 2011): pg. 7742-7747. DOI. This article is @ Royal Society of Chemistry and permission has been granted for this version to appear in e-Publications@Marquette. Royal Society of Chemistry does not grant permission for this article to be further copied/distributed or hosted elsewhere without the express permission from Royal Society of Chemistry. 


\section{Introduction}

The (+)-frondosins A-E (1A-E, Fig. 1, Scheme 1) are a family of sesquiterpenes hydroquinone derivatives isolated from the sponge Dysidea frondosa in $1997 .{ }^{1}$ These compounds were found to inhibit the binding of interleukin-8 (IL-8) to its receptor in the micromolar range, with $\mathbf{1 A}$ and $\mathbf{1 B}$ being the most active ( $\mathrm{IC}_{50}=3.4$ and $9.6 \mathrm{mM}$, respectively). Since IL- 8 is involved in enlisting neutrophiles to a site of inflammation, inhibitors of IL-8 might be useful in treating autoimmune disorders as well as tumor suppression. Additionally, frondosins $A$ and $D$ of the opposite optical rotation were found in organic extracts of Euryspongia sp which exhibited HIV inhibitory activity. ${ }^{1 \mathrm{~b}}$ More recently, liphagal (2), a structurally related compound was isolated from the sponge Aka coralliphaga. ${ }^{2}$ Liphagal was found to be a selective inhibitor of PI3 kinase a at $100 \mathrm{nM}$ level. In addition to their intriguing biological activity, the structural complexity of $\mathbf{1 A - E}$ and $\mathbf{2}$ has generated significant synthetic interest. ${ }^{3,4}$

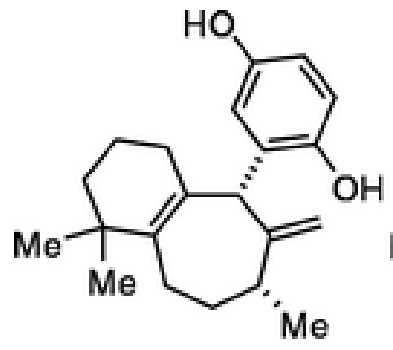

$1 \mathrm{~A}$

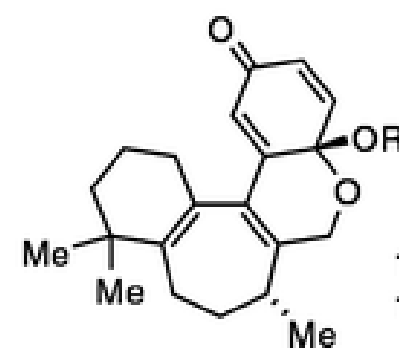

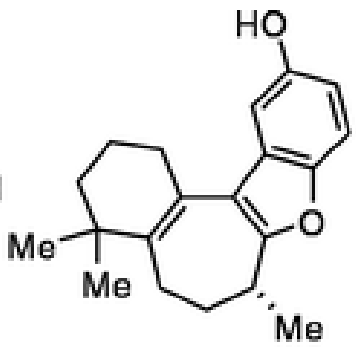

$1 B$

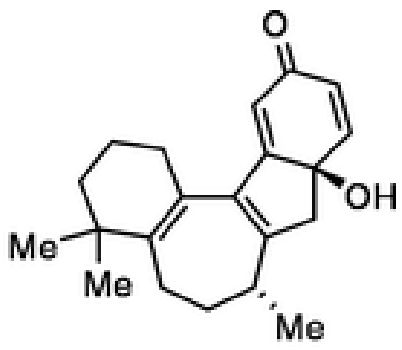

$1 \mathrm{C}$ (1) 
rearrangement to afford 1,4-cycloheptadienes 6 . We have previously utilized this methodology for the preparation of the 5-7-5 fused ring system of the guianolides. ${ }^{5 d}$ We herein report on synthetic studies directed toward frondosins $A$ and $B$ which utilizes this methodology for the formation of the seven-membered ring (Scheme 2).

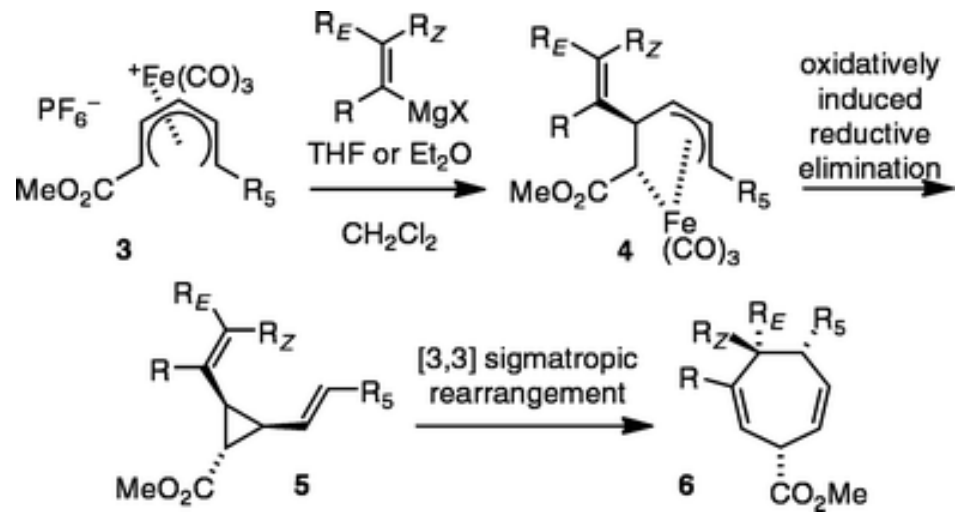

\section{Scheme 2}

\section{Results and discussion}

The reaction of tricarbonyl(methyl 6-oxo-2,4-hexadienoate)iron 7 with the Grignard formed from 1-bromo-2,5-dimethoxybenzene gave (dienol)iron complex 8, which upon dehydration with $\mathrm{HPF}_{6} /$ acetic anhydride afforded the acyclic (pentadienyl)iron(1+) cation 9a (Scheme 3). This cation was assigned a cisoid structure on the basis of its ${ }^{1} \mathrm{H}$ NMR spectral data. In particular, the signals for $\mathrm{H}-2$ and $\mathrm{H}-4$ each appear as a doublet of doublets $(J=\mathrm{ca} .7$ and $11-14 \mathrm{~Hz})$; the larger couplings are consistent with a trans orientation with $\mathrm{H}-1$ and $\mathrm{H}-$ 5 respectively. The chemical shifts and coupling constants for $9 \mathbf{a}$ are similar to those reported for the (1-methoxycarbonyl-5phenylpentadienyl $) \mathrm{Fe}(\mathrm{CO})_{3}{ }^{+}$cation $\mathbf{9 b} .^{6}$ 


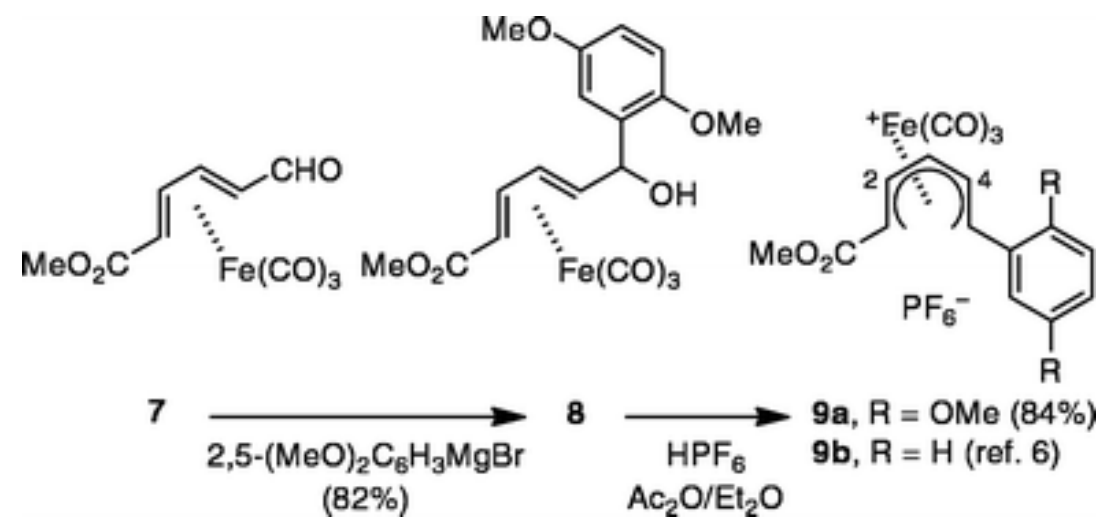

\section{Scheme 3}

Reaction of $( \pm)-\mathbf{9 a}$, in methylene chloride, with commercially available isopropenylmagnesium bromide in THF, gave a separable mixture of isomeric complexes $( \pm)-\mathbf{1 0}$ and $( \pm) \mathbf{1 1}$ (Scheme 4). The structures of $\mathbf{1 0}$ and $\mathbf{1 1}$ were tentatively assigned on the basis of their NMR spectral data; in particular, the three separate signals at $\delta 200-$ 212 , the signal at $\delta 94-100$ and the signal at $\delta 11-15 \mathrm{ppm}$ in the ${ }^{13} \mathrm{C}$ NMR spectra of each $\mathbf{1 0}$ and $\mathbf{1 1}$ are characteristic of the three metal carbonyls, the central allyl carbon and the carbon $\sigma$-bonded to iron in (3-pentene-1,5-diyl)iron complexes. ${ }^{6}$ (Pentenediyl)iron complex 10 was tentatively assigned as resulting from nucleophilic attack at C-2 of 9 by comparison of its ${ }^{1} \mathrm{H}$ NMR spectral data with a similar 2substituted-(5-aryl-1-methoxycarbonylpent-3-ene-1,5-diyl)iron complex produced from $\mathbf{9 b},{ }^{6}$ while $\mathbf{1 1}$ was assigned a 4-substituted(5-aryl-1-methoxycarbonylpent-2-ene-1,5-diyl)iron structure in order to be unique from 10. These tentative structural assignments were eventually corroborated by single crystal diffraction analysis of each. $\neq$

Organic and Biomolecular Chemistry, Vol. 9, No. 22 (November 2011): pg. 7742-7747. DOI. This article is @ Royal Society of Chemistry and permission has been granted for this version to appear in e-Publications@Marquette. Royal Society of Chemistry does not grant permission for this article to be further copied/distributed or hosted elsewhere without the express permission from Royal Society of Chemistry. 


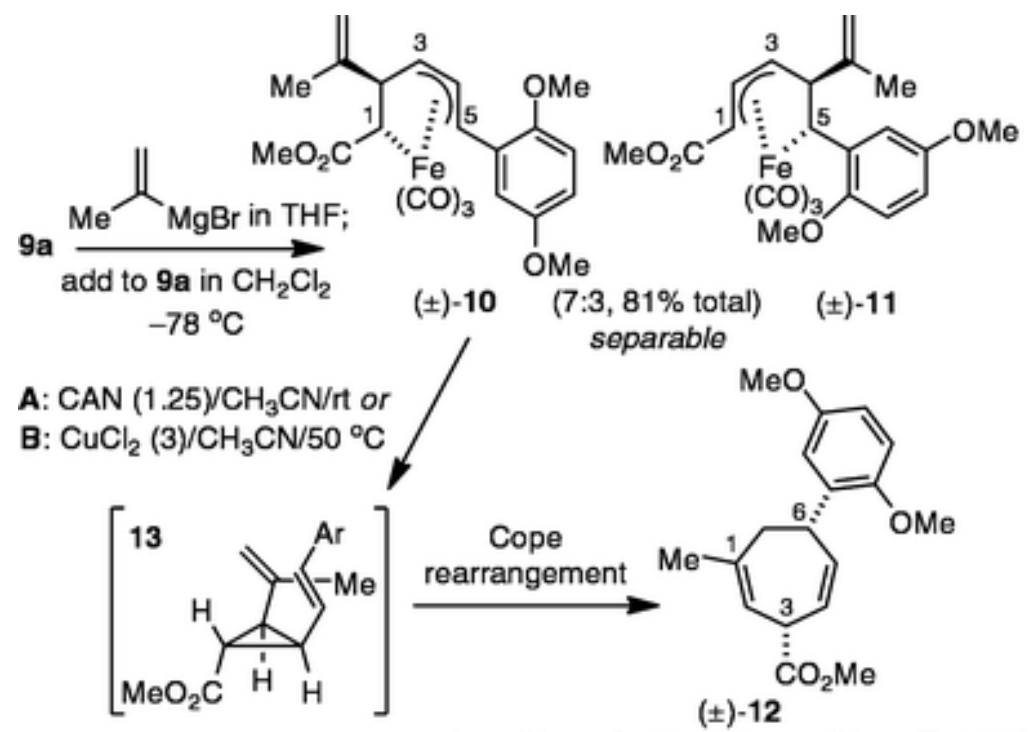

(conditions A, 26-45\%; conditions B, 95\%)

Scheme $4(\operatorname{Ar}=2,5$-dimethoxyphenyl).

Oxidative decomplexation of $\mathbf{1 0}$ with cerium ammonium nitrate (CAN) gave the cycloheptadiene ( \pm )-12 in low and variable yield (conditions A, Scheme 4). This reaction presumably proceeds via the intermediacy of the cis-divinylcyclopropane 13, which was not observed. The low yield of this product may be due to further oxidation of the $p$-dimethoxybenzene ring with CAN to afford a $p$-quinone substituted product. Oxidative decomplexation of $\mathbf{1 0}$ with $\mathrm{CuCl}_{2}$ (conditions $\mathbf{B}$, Scheme 4) gave $\mathbf{1 2}$ in considerably improved yield (95\%). Attempts to use $\mathrm{CuBr}_{2}, \mathrm{Ag}_{2} \mathrm{O}, \mathrm{Pb}(\mathrm{OAc})_{4}$ or Dess-Martin periodinane for oxidative decomplexation were unsuccessful, giving only unreacted starting material. The structure of $\mathbf{1 2}$ was assigned on the basis of its NMR spectral data; in particular signals for the three olefinic protons appear at $\delta 5.65-5.75(2 \mathrm{H})$ and $6.04(1 \mathrm{H}) \mathrm{ppm}$, while multiplets at 4.07-4.14 and 4.25-4.31 ppm correspond to $\mathrm{H}-3$ and $\mathrm{H}-$ 6.

With successful model studies completed, attention was turned to preparing the bicyclo[5.4.0] undecane scaffold of the frondosins. In our hands, attempts to prepare the Grignard reagent from commercially available 1-bromocyclohexene (14a) were unsuccessful. ${ }^{7}$ For this reason, it was necessary to prepare 1-cyclohexenyllithium by lithium-halogen exchange using $t$-BuLi/pentane. Addition of a solution of this organolithium reagent, prepared in $T H F$, to $9 a$ in $\mathrm{CH}_{2} \mathrm{Cl}_{2}$ 
$\left(-78^{\circ} \mathrm{C}\right.$ ) gave the 2-substituted (pentenediyl)iron complex 15 (eqn (1)). This segment of the structure was assigned by comparison of portions of its NMR spectral data with those for 10; in particular the chemical shifts for $\mathrm{H}-1, \mathrm{H}-2, \mathrm{H}-3, \mathrm{H}-4$, and $\mathrm{H}-5$ of $15(\delta 0.68, c a .3 .7$, $4.45,5.44$ and $4.50 \mathrm{ppm}$ ) are similar to those for $\mathbf{1 0}$. The exact nature of the substituent at C-2 was initially unclear, however single crystal diffraction analysis $\neq$ revealed this to be a dichloromethyl substituent. Presumably 15 arises via deprotonation of the $\mathrm{CH}_{2} \mathrm{Cl}_{2}$ solvent, followed by nucleophilic addition of the resultant dichloromethyl anion at C-2.

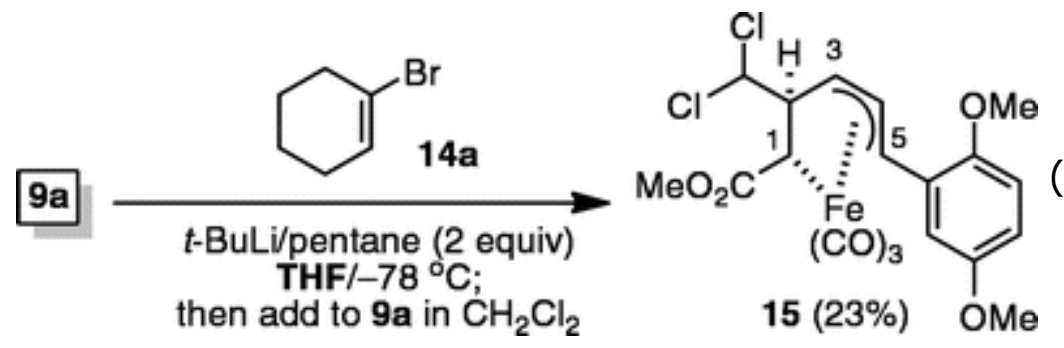

In contrast, addition of the organolithium reagent from 1bromocyclohexene by lithium-halogen exchange, prepared in ether/pentane, to $9 \mathbf{a}$ in $\mathrm{CH}_{2} \mathrm{Cl}_{2}\left(-78^{\circ} \mathrm{C}\right)$ gave a separable mixture of 16a and 17a (Scheme 5). Complex 16a was assigned a (pentenediyl)iron structure by comparison of its NMR spectral data with that for 10. This assignment was corroborated by single crystal diffraction analysis. $\neq$ The structure of 17a was assigned on the basis of its NMR spectral data. In particular signals at $\delta 2.81$ (d), 5.24 (dd) and 5.98 ( $d d, J=5.3$ and 10.5 ) in the ${ }^{1} \mathrm{H}$ NMR spectrum and signals at $\delta 80.4$ and $88.9 \mathrm{ppm}$ in the ${ }^{13} \mathrm{C}$ NMR spectrum and are characteristic of $\mathrm{H}-2, \mathrm{H}-3, \mathrm{H}-4, \mathrm{C}-3$ and $\mathrm{C}-4$ of $(2 E, 4 Z$-hexadienoate $) \mathrm{Fe}(\mathrm{CO})_{3}$ complexes. ${ }^{6,8}$ In a similar fashion, addition of the organolithium reagent prepared by lithium-halogen exchange of 6,6-dimethyl-1iodocyclohexene $(\mathbf{1 4 b})^{9}$ in ether/pentane, to $\mathbf{9 a}$ in $\mathrm{CH}_{2} \mathrm{Cl}_{2}\left(-78{ }^{\circ} \mathrm{C}\right)$ gave a separable mixture of $\mathbf{1 6} \mathbf{b}$ and $\mathbf{1 7 b}$ (Scheme 5). The structures of $\mathbf{1 6 b}$ and 17b were assigned by comparison of their NMR spectral data with those for $\mathbf{1 6 a}$ and $\mathbf{1 7 a}$. The structural assignment for $\mathbf{1 6} \mathbf{b}$ was corroborated by single crystal diffraction analysis (Fig. 1).

Organic and Biomolecular Chemistry, Vol. 9, No. 22 (November 2011): pg. 7742-7747. DOI. This article is @ Royal Society of Chemistry and permission has been granted for this version to appear in e-Publications@Marquette. Royal Society of Chemistry does not grant permission for this article to be further copied/distributed or hosted elsewhere without the express permission from Royal Society of Chemistry. 


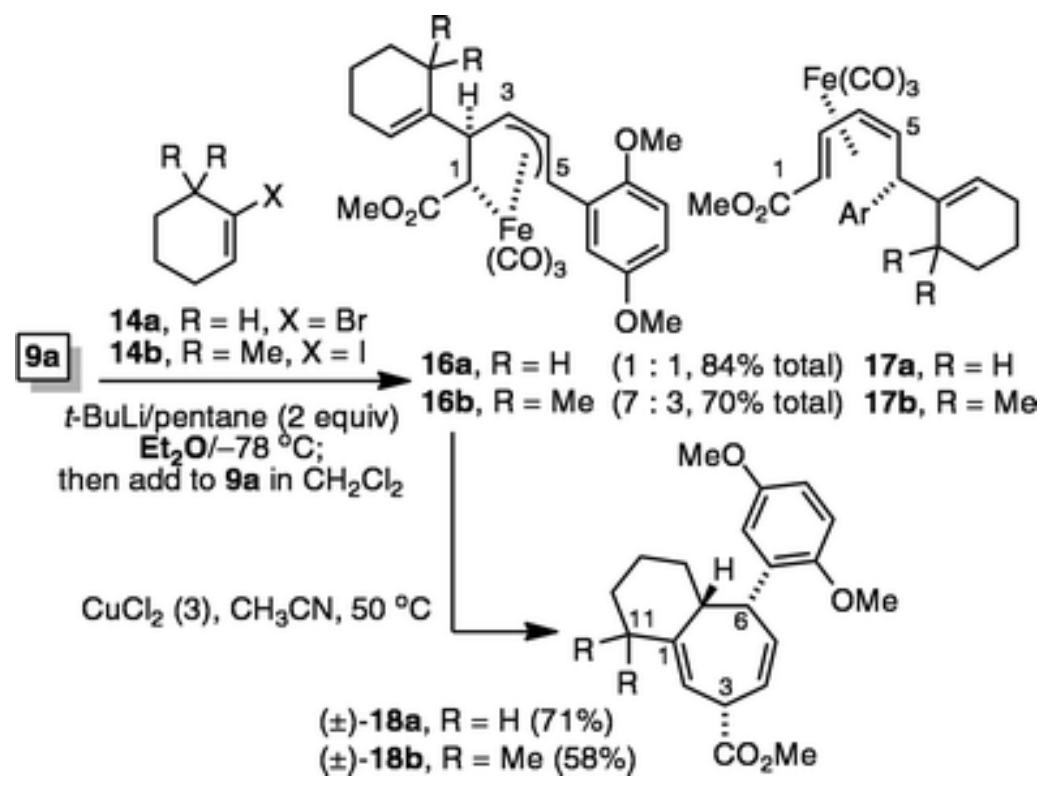

Scheme 5 ( $\operatorname{Ar}=2,5$-dimethoxyphenyl).

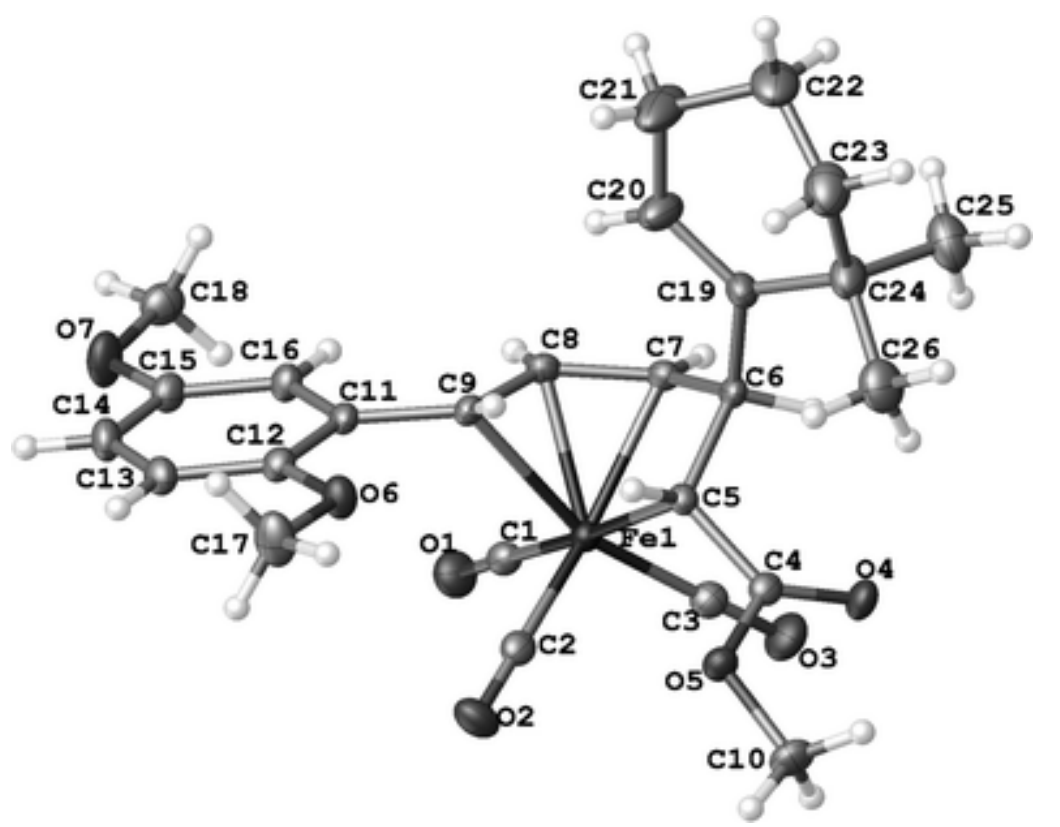

Fig. 1 Molecular structure of $( \pm)$-16b (arbitrary atom numbering).

The origin of the differences in the reactivity of $9 \mathbf{a}$ with the alkenylmetal species indicated above is presently unclear. However, the results reveal that the regioselectivity of this reaction may depend on such subtle factors as the aggregation of these organometal species. ${ }^{10}$

Organic and Biomolecular Chemistry, Vol. 9, No. 22 (November 2011): pg. 7742-7747. DOI. This article is @ Royal Society of Chemistry and permission has been granted for this version to appear in e-Publications@Marquette. Royal Society of Chemistry does not grant permission for this article to be further copied/distributed or hosted elsewhere without the express permission from Royal Society of Chemistry. 
NOT THE PUBLISHED VERSION; this is the author's final, peer-reviewed manuscript. The published version may be accessed by following the link in the citation at the bottom of the page.

Oxidative decomplexation of $\mathbf{1 6 a}$ or $\mathbf{1 6} \mathbf{b}$ with $\mathrm{CuCl}_{2}$ gave the bicyclo[5.4.0] undecadiene products $( \pm) \mathbf{- 1 8 a}$ or $( \pm) \mathbf{- 1 8 b}$, respectively. The structures of $\mathbf{1 8 a / 1 8 b}$ were assigned by comparison of their NMR spectral data with that for $\mathbf{1 2}$.

\section{Conclusions}

A 4-step route from (methyl 6-oxo-2,4-hexadienoate) $\mathrm{Fe}(\mathrm{CO})_{3}$ to the 2-arylbicyclo[5.4.0] undecane scaffold of the frondosins was developed. This route relies on nucleophilic addition of an alkenylmetal species to the acyclic (pentadienyl)iron cation 9a. The low regioselectivity of this nucleophilic addition remains a challenge in this approach. A modified approach to the requisite (pentenediyl)iron complex 16b, which addresses this limitation, is under investigation and results will be reported in due course.

\section{Experimental}

\section{General methods}

All reactions involving moisture or air sensitive reagents were carried out under a nitrogen atmosphere in oven-dried glassware with anhydrous solvents. Purifications by chromatography were carried out using silica gel $60(40-63 \mu \mathrm{m})$. NMR spectra were recorded on either a Varian Mercury+ $300 \mathrm{MHz}$ or a Varian UnityInova $400 \mathrm{MHz}$ instrument. $\mathrm{CDCl}_{3}$ and $\mathrm{CD}_{3} \mathrm{NO}_{2}$ were purchased from Cambridge Isotope Laboratories. ${ }^{1} \mathrm{H}$ NMR spectra were calibrated to $7.27 \mathrm{ppm}$ for residual $\mathrm{CHCl}_{3}$ or $4.33 \mathrm{ppm}$ for $\mathrm{CD}_{2} \mathrm{HNO}_{2} .{ }^{13} \mathrm{C} \mathrm{NMR}$ spectra were calibrated from the central peak at $77.23 \mathrm{ppm}$ for $\mathrm{CDCl}_{3}$ or 60.5 for $\mathrm{CD}_{3} \mathrm{NO}_{2}$. Coupling constants are reported in $\mathrm{Hz}$. Elemental analyses were obtained from Midwest Microlabs, Ltd., Indianapolis, IN, USA, and high-resolution mass spectra were obtained from the University of Nebraska Center for Mass Spectrometry or the COSMIC lab at Old Dominion University. 1-Bromocyclohexene was purchased from Combi-Blocks, LLC, San Diego, CA, USA. 6,6-Dimethyl-1-iodocyclohexene was prepared from 2,2-dimethylcyclohexanone according to the literature procedure. ${ }^{9}$

Organic and Biomolecular Chemistry, Vol. 9, No. 22 (November 2011): pg. 7742-7747. DOI. This article is @ Royal Society of Chemistry and permission has been granted for this version to appear in e-Publications@Marquette. Royal Society of Chemistry does not grant permission for this article to be further copied/distributed or hosted elsewhere without the express permission from Royal Society of Chemistry. 


\section{Tricarbonyl[1-methoxycarbonyl-5-(2',5'-dimethoxy- phenyl)pentadienyl]iron(1+) hexafluorophosphate 9a}

To a three necked $300 \mathrm{~mL}$ round-bottomed flask, equipped with a dropping funnel, condenser and a stirring bar, were charged $\mathrm{Mg}$ turnings $(0.54 \mathrm{~g}, 22 \mathrm{mmol})$ and freshly distilled dry THF $(30 \mathrm{~mL})$ under nitrogen. A solution of 1-bromo-2,5-dimethoxybenzene (4.40 g, 20.3 $\mathrm{mmol})$ in dry THF $(10 \mathrm{~mL})$ was added dropwise with vigorous stirring under nitrogen. After addition was complete, the reaction mixture was heated at reflux for $30 \mathrm{~min}$. To a solution of $7(5.20 \mathrm{~g}, 18.6 \mathrm{mmol})$ in dry THF ( $70 \mathrm{~mL})$, cooled to $-40^{\circ} \mathrm{C}$, was added dropwise, over $15 \mathrm{~min}$, the previously prepared Grignard solution. After addition was complete, the cooling bath was removed and the reaction mixture was warmed to room temperature and stirred for $3 \mathrm{~h}$. Water $(30 \mathrm{~mL})$ was cautiously added, and the mixture was extracted several times with ethyl acetate. The combined extracts were dried $\left(\mathrm{MgSO}_{4}\right)$ and concentrated to give a crude compound $8(6.40 \mathrm{~g}, 82 \%) . \delta_{\mathrm{H}}(300 \mathrm{MHz}$, $\left.\mathrm{CDCl}_{3}\right) 1.04(1 \mathrm{H}, \mathrm{d}, \mathrm{J}=7.8, \mathrm{H}-2), 1.80(1 \mathrm{H}, \mathrm{t}, \mathrm{J}=8.1, \mathrm{H}-5), 3.01(1 \mathrm{H}$, $\mathrm{d}, \mathrm{J}=8.1, \mathrm{OH}), 3.65(3 \mathrm{H}, \mathrm{s}, \mathrm{OMe}), 3.78(3 \mathrm{H}, \mathrm{s}, \mathrm{OMe}), 3.85(3 \mathrm{H}, \mathrm{s}$, $\mathrm{OMe}), 4.64(1 \mathrm{H}, \mathrm{t}, \mathrm{J}=7.5, \mathrm{H}-6), 5.67(1 \mathrm{H}, \mathrm{dd}, \mathrm{J}=4.8$ and 9.0, $\mathrm{H}-4)$, $5.82(1 \mathrm{H}, \mathrm{dd}, \mathrm{J}=4.8$ and $9.0, \mathrm{H}-3), 6.80-6.90(3 \mathrm{H}, \mathrm{m}, \mathrm{ArH}) ; \delta_{\mathrm{c}}(75$ $\left.\mathrm{MHz}, \mathrm{CDCl}_{3}\right) 46.1,51.8,55.8,55.9,66.6,73.7,83.6,85.7,111.8$, $113.4,113.6,132.1,150.6,154.0,172.8$ (signal for Fe-CO not observed). This compound was used in the next step without further purification. To an ice cold solution of crude $8(3.00 \mathrm{~g}, 7.18 \mathrm{mmol})$ and acetic anhydride $(2.2 \mathrm{~mL})$ in dry ether $(10 \mathrm{~mL})$ was added dropwise a cold solution of $\mathrm{HPF}_{6}\left(60 \mathrm{wt} \%\right.$ in $\mathrm{H}_{2} \mathrm{O}, 2.46 \mathrm{~mL}, 10.1 \mathrm{mmol}$ ) in acetic anhydride $(4.5 \mathrm{~mL})$. An orange precipitate developed and the reaction mixture was stirred for $20 \mathrm{~min}$ and then added to a large excess of ether. The solid was collected by filtration through a sintered-glass funnel, and the solid was washed several times with dry ether.

Recrystallization from $\mathrm{CH}_{2} \mathrm{Cl}_{2}$ /hexanes gave $9 a$ ( $\left.3.30 \mathrm{~g}, 84 \%\right)$ as a bright orange solid (Found: $\mathrm{C}, 39.24 ; \mathrm{H}, 3.36$. Calcd for $\mathrm{C}_{18} \mathrm{H}_{17} \mathrm{O}_{7} \mathrm{FePF}_{6}$ : $\mathrm{C}, 39.59 ; \mathrm{H}, 3.14.) ; \mathrm{V}_{\max }(\mathrm{KBr}) / \mathrm{cm}^{-1} 2116,2081$ and $1717 ; \delta_{\mathrm{H}}(300$ $\left.\mathrm{MHz}, \mathrm{CD}_{3} \mathrm{NO}_{2}\right) 3.14(1 \mathrm{H}, \mathrm{d}, \mathrm{J}=10.8, \mathrm{H}-1), 3.81(3 \mathrm{H}, \mathrm{s}, \mathrm{OMe}), 3.92$ $(3 \mathrm{H}, \mathrm{s}, \mathrm{OMe}), 4.01(3 \mathrm{H}, \mathrm{s}, \mathrm{OMe}), 4.78(1 \mathrm{H}, \mathrm{d}, \mathrm{J}=13.5, \mathrm{H}-5), 6.70$ $(1 \mathrm{H}, \mathrm{dd}, \mathrm{J}=7.2$ and $10.5, \mathrm{H}-2), 6.96(1 \mathrm{H}, \mathrm{dd}, J=7.1$ and $13.5, \mathrm{H}-4)$, 7.12-7.26 (4H, $\mathrm{m}, \mathrm{H}-3$ and $\mathrm{ArH}) ; \delta_{\mathrm{c}}\left(75 \mathrm{MHz}, \mathrm{CD}_{3} \mathrm{NO}_{2}\right) 52.2,54.3$, $54.7,61.3,92.5,95.4,95.9,102.6,111.0,112.4,119.6,120.2$, 
NOT THE PUBLISHED VERSION; this is the author's final, peer-reviewed manuscript. The published version may be accessed by following the link in the citation at the bottom of the page.

$152.5,153.3,168.1$ (the signals for the metal carbonyls were not observed).

\section{Reaction of 9a with isopropenylmagnesium bromide}

To a solution of cation $9 \mathrm{a}(0.55 \mathrm{~g}, 1.0 \mathrm{mmol})$ in dry $\mathrm{CH}_{2} \mathrm{Cl}_{2}(40$ $\mathrm{mL}$ ) in a $100 \mathrm{~mL}$ Schlenk flask $-78{ }^{\circ} \mathrm{C}$ under nitrogen, was slowly added a solution of isopropenylmagnesium bromide $(0.5 \mathrm{M}$ solution in THF, $2.2 \mathrm{~mL}, 1.1 \mathrm{mmol})$. The reaction mixture was stirred at $-78^{\circ} \mathrm{C}$ for $1 \mathrm{~h}$, and then slowly warmed to room temperature. Saturated $\mathrm{NH}_{4} \mathrm{Cl}$ solution (10 $\mathrm{mL}$ ) was added and the resulting mixture was extracted several times with $\mathrm{CH}_{2} \mathrm{Cl}_{2}$. The combined extracts were dried $\left(\mathrm{MgSO}_{4}\right)$ and concentrated to give a mixture of 10 and 11 (71: 29 by ${ }^{1} \mathrm{H}$ NMR integration; $0.36 \mathrm{~g}, 81 \%$ ) as a yellow solid. The mixture was separated by purification over column chromatography (hexanes-ethyl acetate $=20: 1 \rightarrow 4: 1$ gradient). Single crystals of 10 and of $\mathbf{1 1}$, suitable for X-ray diffraction, were obtained by slow evaporation of concentrated $\mathrm{CH}_{2} \mathrm{Cl}_{2}$ /hexanes (1:9) solutions at room temperature.

\section{Tricarbonyl[ 1-methoxycarbonyl-5-(2',5'-dimethoxy-} phenyl)-2-(1-methylethenyl)-3-pentene-1,5-diyl)iron ( \pm )-10. (Found: $\mathrm{C}, 57.16 ; \mathrm{H}, 5.01$. Calcd for $\mathrm{C}_{21} \mathrm{H}_{22} \mathrm{O}$ Fe: $\mathrm{C}, 57.03 ; \mathrm{H}, 5.01$ ); mp 136-139 ${ }^{\circ} \mathrm{C} ; \delta_{\mathrm{H}}\left(400 \mathrm{MHz} \mathrm{CDCl}_{3}\right) 0.78(1 \mathrm{H}, \mathrm{d}, J=8.9, \mathrm{H}-1), 1.56$ $(3 \mathrm{H}, \mathrm{s}, \mathrm{C}=\mathrm{CMe}), 3.70-3.83(1 \mathrm{H}, \mathrm{m}, \mathrm{H}-2), 3.72(3 \mathrm{H}, \mathrm{s}, \mathrm{OMe}), 3.76(3 \mathrm{H}$, $\mathrm{s}, \mathrm{OMe}), 3.89(3 \mathrm{H}, \mathrm{s}, \mathrm{OMe}), 4.37(1 \mathrm{H}, \mathrm{t}, \mathrm{J}=7.4, \mathrm{H}-3), 4.45(1 \mathrm{H}, \mathrm{d}, \mathrm{J}$ $=12.3, \mathrm{H}-5), 4.61$ and $4.63\left(2 \mathrm{H}, 2 \times \mathrm{s}, \mathrm{C}=\mathrm{CH}_{2}\right), 5.46(1 \mathrm{H}, \mathrm{dd}, J=7.1$ and 12.5, H-4), 6.75-6.82 (3H, $\mathrm{m}, \mathrm{ArH}) ; \delta_{\mathrm{c}}\left(100 \mathrm{MHz} \mathrm{CDCl}_{3}\right)$ 11.7, 19.6, 45.4, 51.6, 55.9, 56.0, 57.7, 70.2, 94.1, 109.2, 109.5, 111.7, $113.0,129.1,147.4,151.5,153.7,181.1,204.6,210.2,210.7$.

\section{Tricarbonyl[1-methoxycarbonyl-5-(2',5'-dimethoxy-} phenyl)-4-(1-methylethenyl)-2-pentene-1,5-diyl)iron ( \pm )-11. (Found: $\mathrm{C}, 57.15 ; \mathrm{H}, 5.08$. Calcd for $\mathrm{C}_{21} \mathrm{H}_{22} \mathrm{O}_{7} \mathrm{Fe}: \mathrm{C}, 57.03 ; \mathrm{H}, 5.01$ ); $\mathrm{mp} 117-118{ }^{\circ} \mathrm{C} ; \mathrm{V}_{\max }(\mathrm{KBr}) / \mathrm{cm}^{-1} 2057,1986$ and $1707 ; \delta_{\mathrm{H}}(400 \mathrm{MHz}$, $\left.\mathrm{CDCl}_{3}\right) 1.39(3 \mathrm{H}, \mathrm{s}, \mathrm{C}=\mathrm{CMe}), 1.77(1 \mathrm{H}, \mathrm{d}, \mathrm{J}=10.6, \mathrm{H}-5), 3.23(1 \mathrm{H}, \mathrm{d}$, $J=10.6, \mathrm{H}-1), 3.51(1 \mathrm{H}, \mathrm{t}, J=7.5, \mathrm{H}-4), 3.75-3.85(1 \mathrm{H}, \mathrm{m}, \mathrm{H}-3)$, $3.78(3 \mathrm{H}, \mathrm{s}, \mathrm{OMe}), 3.79(3 \mathrm{H}, \mathrm{s}, \mathrm{OMe}), 3.85(3 \mathrm{H}, \mathrm{s}, \mathrm{OMe}), 4.59(2 \mathrm{H}, \mathrm{s}$, $\left.\mathrm{C}=\mathrm{CH}_{2}\right), 5.44(1 \mathrm{H}, \mathrm{dd}, \mathrm{J}=7.8$ and $10.2, \mathrm{H}-2), 6.61(1 \mathrm{H}, \mathrm{dd}, \mathrm{J}=1.6$ and 8.6, ArH $), 6.69(1 \mathrm{H}, \mathrm{d}, J=8.6, \mathrm{ArH}), 6.94(1 \mathrm{H}, \mathrm{d}, J=1.6, \mathrm{ArH})$; $\delta_{c}\left(100 \mathrm{MHz}_{1} \mathrm{CDCl}_{3}\right)$ 15.0, 20.0, 48.5, 52.1, 55.3, 55.9, 59.9, 62.0, $100.6,109.2,109.3,110.3,111.1,139.0,148.3,151.3,153.5,173.9$, $200.6,210.4,212.4$.

Organic and Biomolecular Chemistry, Vol. 9, No. 22 (November 2011): pg. 7742-7747. DOI. This article is (C) Royal Society of Chemistry and permission has been granted for this version to appear in e-Publications@Marquette. Royal Society of Chemistry does not grant permission for this article to be further copied/distributed or hosted elsewhere without the express permission from Royal Society of Chemistry. 


\section{Tricarbonyl[2-dichloromethyl-1-methoxycarbonyl-5-} (2',5'-dimethoxyphenyl)-3-pentene-1,5-diyl)iron ( \pm )-15. To a stirring solution of 1-bromo-1-cyclohexene $(0.10 \mathrm{~g}, 0.62 \mathrm{mmol})$ in dry THF ( $5 \mathrm{~mL}$ ) at $-78^{\circ} \mathrm{C}$, in a $50 \mathrm{~mL}$ Schlenk flask, was added dropwise a solution of $t$-BuLi ( $1.7 \mathrm{M}$ in pentane, $0.74 \mathrm{~mL}, 1.26 \mathrm{mmol}$ ). After addition was complete, the mixture was stirred at $-78^{\circ} \mathrm{C}$ for $1 \mathrm{~h}$, and then the anion solution was transferred by cannula into a stirring solution of cation $9 a(0.15 \mathrm{~g}, 0.27 \mathrm{mmol})$ in dry $\mathrm{CH}_{2} \mathrm{Cl}_{2}(20 \mathrm{~mL})$ at $-78{ }^{\circ} \mathrm{C}$. To ensure complete transfer of the solution, a further portion of dry THF ( $1 \mathrm{~mL})$ was transferred by cannula from the flask used for anion preparation. The reaction mixture was stirred for $30 \mathrm{~min}$ at $-78{ }^{\circ} \mathrm{C}$, then slowly warmed to $0{ }^{\circ} \mathrm{C}$ for $4 \mathrm{~h}$, and finally quenched with water $(10 \mathrm{~mL})$. The resulting mixture was extracted several times with $\mathrm{CH}_{2} \mathrm{Cl}_{2}$, and the combined extracts were dried $\left(\mathrm{MgSO}_{4}\right)$ and concentrated. The residue was purified by column chromatography (hexanes-ethyl acetate $=20: 1 \rightarrow 4: 1$ gradient) to afford $( \pm$ )-15 (30 $\mathrm{mg}, 23 \%$ ) as a pale yellow solid. Single crystals suitable for X-ray diffraction were obtained from layering in hexanes over a concentrated solution in $\mathrm{CH}_{2} \mathrm{Cl}_{2}$. (Found: $\mathrm{C}, 47.09 ; \mathrm{H}$, 3.99. Calcd for $\mathrm{C}_{19} \mathrm{H}_{21} \mathrm{Cl}_{2} \mathrm{O}_{7} \mathrm{Fe}$ : $\mathrm{C}, 46.75 ; \mathrm{H}, 4.34) ; \mathrm{mp} 163-166^{\circ} \mathrm{C}$ (dec.); $\mathrm{v}_{\max }(\mathrm{KBr}) / \mathrm{cm}^{-1} 2066$, 1995 and 1688; $\delta_{\mathrm{H}}\left(400 \mathrm{MHz}, \mathrm{CDCl}_{3}\right) 0.68(1 \mathrm{H}, \mathrm{d}, J=8.8, \mathrm{H}-1), 3.73$ $(3 \mathrm{H}, \mathrm{s}, \mathrm{OMe}), 3.75-3.80(1 \mathrm{H}, \mathrm{m}, \mathrm{H}-2), 3.76(3 \mathrm{H}, \mathrm{s}, \mathrm{OMe}), 3.92(3 \mathrm{H}, \mathrm{s}$, $\mathrm{OMe}), 4.45(1 \mathrm{H}, \mathrm{t}, \mathrm{J}=7.2, \mathrm{H}-3), 4.50(1 \mathrm{H}, \mathrm{d}, \mathrm{J}=12.9, \mathrm{H}-5), 4.94$ $\left(1 \mathrm{H}, \mathrm{d}, J=10.0,-\mathrm{CHCl}_{2}\right), 5.44(1 \mathrm{H}, \mathrm{dd}, J=7.2$ and $12.8, \mathrm{H}-4), 6.83$ $(1 \mathrm{H}, \mathrm{d}, J=2.6, \mathrm{ArH}), 6.84(1 \mathrm{H}, \mathrm{s}, \mathrm{ArH}), 6.87(1 \mathrm{H}, \mathrm{d}, J=2.4, \mathrm{ArH}) ; \delta_{c}$ $\left(100 \mathrm{MHz}, \mathrm{CDCl}_{3}\right)$ 13.0, 50.3, 51.8, 54.9, 55.91, 55.94, 70.8, 75.8, $93.6,109.3,111.6,113.6,128.0,151.3,153.8,179.5,203.8,209.2$, 209.4 .

\section{Reaction of 9a with cyclohexenyllithium in ether}

To a stirring solution of 1-bromo-1-cyclohexene (174 mg, 1.08 $\mathrm{mmol})$ in dry $\mathrm{Et}_{2} \mathrm{O} /$ dry pentane $(2: 3,1 \mathrm{~mL})$ at $-78^{\circ} \mathrm{C}$, was added dropwise a solution of $t$-BuLi (1.7 M in pentane, $1.28 \mathrm{~mL}, 2.2 \mathrm{mmol}$ ). After addition was complete, the mixture was stirred at $-78^{\circ} \mathrm{C}$ for $1 \mathrm{~h}$, and then the solution was transferred by cannula into a stirring solution of cation 9 a $(300 \mathrm{mg}, 0.549 \mathrm{mmol})$ in dry $\mathrm{CH}_{2} \mathrm{Cl}_{2}(40 \mathrm{~mL})$ at $-78^{\circ} \mathrm{C}$. To ensure complete transfer of the solution, a further portion of dry $\mathrm{Et}_{2} \mathrm{O} / \mathrm{dry}$ pentane $(1 \mathrm{~mL})$ was transferred by cannula from the

Organic and Biomolecular Chemistry, Vol. 9, No. 22 (November 2011): pg. 7742-7747. DOI. This article is @ Royal Society of Chemistry and permission has been granted for this version to appear in e-Publications@Marquette. Royal Society of Chemistry does not grant permission for this article to be further copied/distributed or hosted elsewhere without the express permission from Royal Society of Chemistry. 
flask used for anion preparation. The reaction mixture was stirred for 30 min at $-78^{\circ} \mathrm{C}$, then slowly warmed to room temperature over a 3 $\mathrm{h}$ period, and finally quenched with water $(10 \mathrm{~mL})$. The resulting mixture was extracted several times with $\mathrm{CH}_{2} \mathrm{Cl}_{2}$, and the combined extracts were dried $\left(\mathrm{MgSO}_{4}\right)$ and concentrated to give a mixture of 16a and 17a (50 : 50 by ${ }^{1} \mathrm{H}$ NMR integration; $222 \mathrm{mg}, 84 \%$ ) as a sticky yellow solid. The mixture was separated by column chromatography (hexanes-ethyl acetate $=20: 1 \rightarrow 4: 1$ gradient). Crystals of 16a suitable for X-ray diffraction were obtained by slow evaporation from a concentrated $\mathrm{CH}_{2} \mathrm{Cl}_{2}$ /hexanes ( $\left.1: 9\right)$ solution at room temperature.

Tricarbonyl[2-(1'-cyclohexenyl)-1-methoxycarbonyl-5(2',5'-dimethoxy-phenyl)-3-pentene-1,5-diyl)iron ( \pm )-16a.

(Found: $\mathrm{C}, 59.53 ; \mathrm{H}, 5.67$. Calcd for $\mathrm{C}_{24} \mathrm{H}_{26} \mathrm{O}$ Fee: $\mathrm{C}, 59.77 ; \mathrm{H}, 5.43$ ); $\mathrm{mp} 147-150{ }^{\circ} \mathrm{C}$ (dec.); $\mathrm{v}_{\max }(\mathrm{KBr}) / \mathrm{cm}^{-1} 2058,1989$ and $1682 ; \delta_{\mathrm{H}}(400$ $\left.\mathrm{MHz} \mathrm{CDCl}_{3}\right) 0.76(1 \mathrm{H}, \mathrm{d}, \mathrm{J}=9.1, \mathrm{H}-1), 1.40-1.64(4 \mathrm{H}, \mathrm{m}), 1.74-1.81$ $(2 \mathrm{H}, \mathrm{m}), 1.86-1.95(2 \mathrm{H}, \mathrm{m}), 3.68(1 \mathrm{H}, \mathrm{t}, J=8.3, \mathrm{H}-2), 3.71(3 \mathrm{H}, \mathrm{s}$, OMe $), 3.76(3 \mathrm{H}, \mathrm{s}, \mathrm{OMe}), 3.90(3 \mathrm{H}, \mathrm{s}, \mathrm{OMe}), 4.33(1 \mathrm{H}, \mathrm{t}, \mathrm{J}=7.4, \mathrm{H}-$ 3), $4.44(1 \mathrm{H}, \mathrm{d}, \mathrm{J}=12.2, \mathrm{H}-5), 5.27(1 \mathrm{H}, \mathrm{br} \mathrm{s}, \mathrm{C}=\mathrm{CH}), 5.44(1 \mathrm{H}, \mathrm{dd}, J$ $=7.0$ and 12.4, H-4), 6.76-6.91 $(3 \mathrm{H}, \mathrm{m}, \mathrm{ArH}) ; \delta_{\mathrm{c}}\left(100 \mathrm{MHz}, \mathrm{CDCl}_{3}\right)$ $12.4,22.6,22.7,25.1,25.6,45.5,51.5,55.9,56.0,58.4,70.0,94.4$, $109.5,111.7,112.9,120.0,129.4,139.9,151.5,153.7,181.3,204.6$, 210.3, 210.8 .

Tricarbonyl[methyl 5-(1'-cyclohexenyl)-5-(2',5'-dimethoxyphenyl)-2E,4Z-pentadienoate]iron $( \pm)-17 a . V_{\max }(\mathrm{KBr}) / \mathrm{cm}^{-1}$ 2044, 1973 and $1736 ; \delta_{\mathrm{H}}\left(400 \mathrm{MHz} \mathrm{CDCl}_{3}\right)$ 1.48-1.64 and 1.84-2.02 $(8 \mathrm{H}, \mathrm{m}), 2.81(1 \mathrm{H}, \mathrm{d}, J=11.5, \mathrm{H}-2), 2.97(1 \mathrm{H}, \mathrm{dd}, J=8.1$ and 11.5, $\mathrm{H}-5), 3.60(1 \mathrm{H}, \mathrm{d}, J=10.4, \mathrm{H}-6), 3.75(3 \mathrm{H}, \mathrm{s}, \mathrm{OMe}), 3.79(3 \mathrm{H}, \mathrm{s}$, $\mathrm{OMe}), 3.85(3 \mathrm{H}, \mathrm{s}, \mathrm{OMe}), 5.24(1 \mathrm{H}, \mathrm{dd}, \mathrm{J}=5.5$ and $7.7, \mathrm{H}-4), 5.54$ $(1 \mathrm{H}, \mathrm{br} \mathrm{s}, \mathrm{C}=\mathrm{CH}), 5.98(1 \mathrm{H}, \mathrm{dd}, \mathrm{J}=5.3$ and $10.5, \mathrm{H}-3), 6.68-6.80$ $(3 \mathrm{H}, \mathrm{m}, \mathrm{ArH}) ; \delta_{\mathrm{c}}\left(100 \mathrm{MHz} \mathrm{CDCl}_{3}\right) 22.2,22.9,25.4,26.8,51.8,51.9$, 54.5, 55.9, 56.0, 57.9, 80.4, 88.9, 110.4, 111.4, 112.2, 124.0, 129.8, $137.9,151.0,153.6,173.2,210.8$; ESI-HRMS calcd for $\mathrm{C}_{24} \mathrm{H}_{26} \mathrm{O}_{7} \mathrm{FeNa}$ $\left(\mathrm{M}+\mathrm{Na}^{+}\right): \mathrm{m} / \mathrm{z}$ 505.0926, found: $\mathrm{m} / \mathrm{z}$ 505.0924.

\section{Reaction of 9a with dimethylcyclohexenyllithium}

To a stirring solution of 1-iodo-6,6-dimethylcyclohex-1-ene (310 $\mathrm{mg}, 1.31 \mathrm{mmol})$ in a solution of dry $\mathrm{Et}_{2} \mathrm{O} / \mathrm{dry}$ pentane $(2: 3,1 \mathrm{~mL})$ at 
$-78^{\circ} \mathrm{C}$ in a $50 \mathrm{~mL}$ Schlenk flask, was added dropwise a solution of $t$ BuLi (1.7 $\mathrm{M}$ in pentane, $1.55 \mathrm{~mL}, 2.6 \mathrm{mmol}$ ). After addition was complete, the mixture was stirred at $-78{ }^{\circ} \mathrm{C}$ for $1 \mathrm{~h}$, and then the solution was transferred by cannula into a stirring solution of cation $\mathbf{9 a}$ (360 $\mathrm{mg}, 0.659 \mathrm{mmol}$ ) in dry $\mathrm{CH}_{2} \mathrm{Cl}_{2}(40 \mathrm{~mL})$ at $-78{ }^{\circ} \mathrm{C}$. To ensure complete transfer of the solution, a further portion of dry $\mathrm{Et}_{2} \mathrm{O} / \mathrm{dry}$ pentane $(1 \mathrm{~mL})$ was transferred by cannula from the flask used for anion preparation. The reaction mixture was stirred for $30 \mathrm{~min}$ at $-78^{\circ} \mathrm{C}$, then slowly warmed to room temperature over a $3 \mathrm{~h}$ period, and finally quenched with water $(10 \mathrm{~mL})$. The resulting mixture was extracted several times with $\mathrm{CH}_{2} \mathrm{Cl}_{2}$, and the combined extracts were dried $\left(\mathrm{MgSO}_{4}\right)$ and concentrated to give a mixture of $\mathbf{1 6} \mathbf{b}$ and $\mathbf{1 7} \mathbf{b}$ (69 : 31 by ${ }^{1} \mathrm{H}$ NMR integration; $235 \mathrm{mg}, 70 \%$ ) as a sticky yellow solid. The mixture was separated by column chromatography (hexanes-ethyl acetate $=20: 1 \rightarrow 4: 1$ gradient). Crystals of $\mathbf{1 6 b}$ suitable for $X$-ray diffraction were obtained by slow evaporation of a concentrated $\mathrm{CH}_{2} \mathrm{Cl}_{2}$ /hexanes (1:9) solution at room temperature.

\section{Tricarbonyl[1-methoxycarbonyl-5-(2',5'-dimethoxy-} phenyl)-2-(6',6'-dimethylcyclohex-1'-enyl)-3-pentene-1,5diyl)iron ( \pm )-16b. (Found: $\mathrm{C}, 61.67 ; \mathrm{H}, 6.19$. Calcd for $\mathrm{C}_{26} \mathrm{H}_{30} \mathrm{O} \mathrm{O}_{7} \mathrm{Fe}$ : $\mathrm{C}, 61.19 ; \mathrm{H}, 5.92$.); $\mathrm{mp} 150-152{ }^{\circ} \mathrm{C}$ (dec.); $\mathrm{V}_{\max }(\mathrm{KBr}) / \mathrm{cm}^{-1} 2056$, 2000, and $1691 ; \delta_{\mathrm{H}}\left(400 \mathrm{MHz}, \mathrm{CDCl}_{3}\right) 0.88(1 \mathrm{H}, \mathrm{d}, \mathrm{J}=9.2, \mathrm{H}-1), 0.96$ $(3 \mathrm{H}, \mathrm{s}, \mathrm{Me}), 1.10(3 \mathrm{H}, \mathrm{s}, \mathrm{Me}), 1.47-1.51(2 \mathrm{H}, \mathrm{m}), 1.33-1.37(2 \mathrm{H}, \mathrm{m})$, $1.89-1.93(2 \mathrm{H}, \mathrm{m}), 3.71(3 \mathrm{H}, \mathrm{s}, \mathrm{OMe}), 3.76(3 \mathrm{H}, \mathrm{s}, \mathrm{OMe}), 3.86(1 \mathrm{H}, \mathrm{t}$, $\mathrm{J}=8.6, \mathrm{H}-2), 3.90(3 \mathrm{H}, \mathrm{s}, \mathrm{OMe}), 4.36(1 \mathrm{H}, \mathrm{t}, \mathrm{J}=7.5, \mathrm{H}-3), 4.57(1 \mathrm{H}$, $\mathrm{d}, \mathrm{J}=12.5, \mathrm{H}-5), 5.26(1 \mathrm{H}, \mathrm{t}, J=3.5, \mathrm{C}=\mathrm{CH}), 5.37(1 \mathrm{H}, \mathrm{dd}, J=7.2$ and 12.3, H-4), 6.76-6.90 (2H, m, ArH); $\delta_{\mathrm{c}}\left(100 \mathrm{MHz}, \mathrm{CDCl}_{3}\right) 16.3$, 19.0, 26.3, 28.4, 29.5, 34.0, 40.8, 41.6, 51.5, 56.0, 56.1, 61.2, 69.4, 93.5, 109.5, 111.7, 112.9, 123.7, 129.6, 148.2, 151.5, 153.8, 180.7, 204.8, 210.5, 210.8. ESI-HRMS calcd for $\mathrm{C}_{26} \mathrm{H}_{30} \mathrm{O}_{7} \mathrm{FeNa}\left(\mathrm{M}+\mathrm{Na}^{+}\right): \mathrm{m} / \mathrm{z}$ 533.1239. Found: $m / z 533.1232$.

TricarbonyI [methyl 5-(2',5'-dimethoxyphenyl)-5-(6',6'dimethylcyclohex-1'-enyl)-2E,4Z-pentadienoate]iron ( \pm )-17b. $V_{\max }(\mathrm{KBr}) / \mathrm{cm}^{-1} 2042,1991,1958$ and $1720 ; \delta_{\mathrm{H}}\left(400 \mathrm{MHz}, \mathrm{CDCl}_{3}\right)$ $0.87(3 \mathrm{H}, \mathrm{s}, \mathrm{Me}), 0.95(3 \mathrm{H}, \mathrm{s}, \mathrm{Me}), 1.38-1.60(4 \mathrm{H}, \mathrm{m}), 1.98-2.04$ $(2 \mathrm{H}, \mathrm{m}), 2.94-3.05(2 \mathrm{H}, \mathrm{m}), 3.75(3 \mathrm{H}, \mathrm{s}, \mathrm{OMe}), 3.76(3 \mathrm{H}, \mathrm{s}, \mathrm{OMe})$, $3.86(3 \mathrm{H}, \mathrm{s}, \mathrm{OMe}), 3.87(1 \mathrm{H}, \mathrm{d}, J=10.7, \mathrm{H}-6), 5.19(1 \mathrm{H}, \mathrm{dd}, J=5.5$ and $7.2, \mathrm{H}-4), 5.92-5.98(2 \mathrm{H}, \mathrm{m}, \mathrm{H}-3$ and $\mathrm{C}=\mathrm{CH}), 6.68-6.80(3 \mathrm{H}, \mathrm{m}$, $\mathrm{ArH}) ; \delta_{\mathrm{c}}\left(100 \mathrm{MHz}_{1} \mathrm{CDCl}_{3}\right) \delta 19.1,26.5,28.1,28.4,35.6,40.0,42.7$,

Organic and Biomolecular Chemistry, Vol. 9, No. 22 (November 2011): pg. 7742-7747. DOI. This article is @ Royal Society of Chemistry and permission has been granted for this version to appear in e-Publications@Marquette. Royal Society of Chemistry does not grant permission for this article to be further copied/distributed or hosted elsewhere without the express permission from Royal Society of Chemistry. 
$51.9,53.5,56.0,56.2,62.7,80.1,89.1,110.4,111.8,112.3,125.8$, 130.0, 146.0, 151.1, 153.7, 174.3, 210.8; ESI-HRMS calcd for $\mathrm{C}_{26} \mathrm{H}_{30} \mathrm{O} 7 \mathrm{FeNa}\left(\mathrm{M}+\mathrm{Na}^{+}\right): m / z$ 533.1239. Found: $m / z$ 533.1219.

3-Methoxycarbonyl-7-(2',5'-dimethoxyphenyl)-1-methyl1,4-cycloheptadiene $( \pm)-12$. To a stirring solution of complex 10 (100 $\mathrm{mg}, 0.226 \mathrm{mmol})$ in $\mathrm{CH}_{3} \mathrm{CN}(3 \mathrm{~mL})$ at room temperature, was slowly added a solution of $\mathrm{CuCl}_{2}(91 \mathrm{mg}, 0.68 \mathrm{mmol})$ in $\mathrm{CH}_{3} \mathrm{CN}(10$ $\mathrm{mL}$ ). The solution was stirred at room temperature for 30 min and then warmed to $50^{\circ} \mathrm{C}$ with stirring for $1 \mathrm{~h}$. After cooling to room temperature, the solution was concentrated and the residue was taken up in $\mathrm{CH}_{2} \mathrm{Cl}_{2}$ and charged onto a silica gel column. Purification by column chromatography (hexanes-ethyl acetate $=20: 1 \rightarrow 10: 1$ gradient) gave $( \pm)-\mathbf{1 2}(65 \mathrm{mg}, 95 \%)$ as a colorless oil. $\delta_{\mathrm{H}}(300 \mathrm{MHz}$, $\left.\mathrm{CDCl}_{3}\right) 1.41(3 \mathrm{H}, \mathrm{t}, \mathrm{J}=1.8, \mathrm{Me}), 2.37(1 \mathrm{H}, \mathrm{dd}, \mathrm{J}=7.5$ and $14.5, \mathrm{H}-7)$, $2.64\left(1 \mathrm{H}, \mathrm{dd}, \mathrm{J}=3.9\right.$ and $\left.14.5, \mathrm{H}-7^{\prime}\right), 3.76(3 \mathrm{H}, \mathrm{s}, \mathrm{OMe}), 3.77(3 \mathrm{H}, \mathrm{s}$, $\mathrm{OMe}), 3.81(3 \mathrm{H}, \mathrm{s}, \mathrm{OMe}), 4.07-4.14(1 \mathrm{H}, \mathrm{m}), 4.25-4.31(1 \mathrm{H}, \mathrm{m})$, 5.65-5.75 $(2 \mathrm{H}, \mathrm{m}), 6.04(1 \mathrm{H}, \mathrm{dddd}, J=1.2,2.1,3.9$ and 11.4$), 6.72$ $(1 \mathrm{H}, \mathrm{dd}, J=3.3$ and 8.7, ArH $), 6.79(1 \mathrm{H}, \mathrm{d}, J=8.7, \mathrm{ArH}), 6.82(1 \mathrm{H}$, $\mathrm{d}, \mathrm{J}=3.3, \mathrm{ArH}) ; \delta_{\mathrm{c}}\left(75 \mathrm{MHz}, \mathrm{CDCl}_{3}\right) 26.1,35.1,36.7,43.5,52.4$, 55.9, 56.2, 111.3, 111.5, 115.8, 122.3, 127.3, 133.6, 134.2, 139.1, 151.0, 153.7, 174.5; FAB-HRMS calcd for $\mathrm{C}_{18} \mathrm{H}_{22} \mathrm{O}_{4}\left(\mathrm{M}^{+}\right) 302.1518$, found 302.1526 .

\section{3-Methoxycarbonyl-6-(2',5'-dimethoxyphenyl)-} bicyclo[5.4.0] undeca-1,4-diene $( \pm)-18 a$. The decomplexation of 16a $(100 \mathrm{mg}, 0.207 \mathrm{mmol})$ with $\mathrm{CuCl}_{2}(84 \mathrm{mg}, 0.63 \mathrm{mmol})$ was carried out in a fashion similar to the decomplexation of $\mathbf{1 0}$.

Purification of the residue by column chromatography $\left(\mathrm{SiO}_{2}\right.$, hexanesethyl acetate $=20: 1 \rightarrow 10: 1$ gradient $)$ gave $( \pm)-\mathbf{1 8 a}(50 \mathrm{mg}, 71 \%)$ a pale ivory solid product; $\delta_{\mathrm{H}}\left(400 \mathrm{MHz}, \mathrm{CDCl}_{3}\right) 1.10-1.30(3 \mathrm{H}, \mathrm{m})$, 1.58-1.72 $(3 \mathrm{H}, \mathrm{m}), 1.91-2.01(1 \mathrm{H}, \mathrm{m}), 2.06-2.12(1 \mathrm{H}, \mathrm{m}), 2.18-2.26$ $(1 \mathrm{H}, \mathrm{m}), 3.77(3 \mathrm{H}, \mathrm{s}, \mathrm{OMe}), 3.78(3 \mathrm{H}, \mathrm{s}, \mathrm{OMe}), 3.79(3 \mathrm{H}, \mathrm{s}, \mathrm{OMe})$, 4.42-4.48 $(1 \mathrm{H}, \mathrm{m}), 4.68-4.72(1 \mathrm{H}, \mathrm{m}), 5.64(1 \mathrm{H}, \mathrm{br} \mathrm{s}, \mathrm{H}-2), 6.05-$ $6.11(1 \mathrm{H}, \mathrm{m}, \mathrm{H}-3), 6.18(1 \mathrm{H}, \mathrm{dd}, J=4.2$ and $10.2, \mathrm{H}-4), 6.72(1 \mathrm{H}, \mathrm{dd}$, $J=3.0$ and 8.9, ArH $), 6.80(1 \mathrm{H}, \mathrm{d}, J=8.9, \mathrm{ArH}), 6.94(1 \mathrm{H}, \mathrm{d}, J=3.0$, $\mathrm{ArH}) ; \delta_{\mathrm{c}}\left(100 \mathrm{MHz}, \mathrm{CDCl}_{3}\right) 26.2,28.0,28.9,38.2,39.7,42.5,44.6$, $52.4,55.9,56.1,110.7,111.4,116.2,116.6,130.0,131.7,132.1$, $145.8,151.4,153.2,174.9$; ESI-HRMS calcd for $\mathrm{C}_{21} \mathrm{H}_{26} \mathrm{O}_{4} \mathrm{Na}^{+}$ $\left(\mathrm{M}+\mathrm{Na}^{+}\right): m / z$ 365.1723. Found: $m / z$ 365.1728.

Organic and Biomolecular Chemistry, Vol. 9, No. 22 (November 2011): pg. 7742-7747. DOI. This article is @ Royal Society of Chemistry and permission has been granted for this version to appear in e-Publications@Marquette. Royal Society of Chemistry does not grant permission for this article to be further copied/distributed or hosted elsewhere without the express permission from Royal Society of Chemistry. 
3-Methoxycarbonyl-6-( 2',5'-dimethoxyphenyl)-11,11dimethylbicyclo[5.4.0] undeca-1,4-diene ( \pm )-18b. The decomplexation 16b (100 mg, $0.207 \mathrm{mmol})$ with $\mathrm{CuCl}_{2}(79 \mathrm{mg}, 0.58$ $\mathrm{mmol}$ ) was carried out in a fashion similar to the decomplexation of 10. Purification of the residue by column chromatography $\left(\mathrm{SiO}_{2}\right.$, hexanes-ethyl acetate $=20: 1 \rightarrow 10: 1$ gradient) gave $( \pm)-\mathbf{1 8 b}$ (42 $\mathrm{mg}, 58 \%)$ as a pale ivory solid; $\mathrm{v}_{\max }($ neat $) / \mathrm{cm}^{-1} 1734 ; \delta_{\mathrm{H}}(400 \mathrm{MHz}$, $\left.\mathrm{CDCl}_{3}\right) 1.06(3 \mathrm{H}, \mathrm{s}, \mathrm{Me}), 1.08(3 \mathrm{H}, \mathrm{s}, \mathrm{Me}), 1.14-1.28(2 \mathrm{H}, \mathrm{m}), 1.34-$ $1.50(3 \mathrm{H}, \mathrm{m}), 1.59-1.66(1 \mathrm{H}, \mathrm{m}), 2.45(1 \mathrm{H}, \mathrm{qd}, \mathrm{J}=3.2$ and $12.8, \mathrm{H}-$ 7), $3.792(3 \mathrm{H}, \mathrm{s}, \mathrm{OMe}), 3.796(3 \mathrm{H}, \mathrm{s}, \mathrm{OMe}), 3.80(3 \mathrm{H}, \mathrm{s}, \mathrm{OMe}), 4.49$ $(1 \mathrm{H}, \mathrm{q}, \mathrm{J}=3.2, \mathrm{H}-3), 4.69(1 \mathrm{H}, \mathrm{t}, \mathrm{J}=4.0, \mathrm{H}-6), 5.67(1 \mathrm{H}, \mathrm{d}, \mathrm{J}=2.0$, $\mathrm{H}-2), 6.18-6.21(2 \mathrm{H}, \mathrm{m}, \mathrm{H}-4$ and $\mathrm{H}-5), 6.74(1 \mathrm{H}, \mathrm{dd}, \mathrm{J}=2.8$ and 8.8, ArH), $6.82(1 \mathrm{H}, \mathrm{d}, J=8.8, \mathrm{ArH}), 6.98(1 \mathrm{H}, \mathrm{d}, J=2.8, \mathrm{ArH}) ; \delta_{\mathrm{c}}(100$ $\left.\mathrm{MHz}, \mathrm{CDCl}_{3}\right) 22.7,26.1,28.5,30.2,38.3,39.2,40.1,42.5,42.9,52.4$, $55.9,56.1,110.5,111.5,114.0,116.3,129.9,131.5,132.3,151.4$, 152.1, 153.2, 175.3. ESI-HRMS Calc. for $\mathrm{C}_{23} \mathrm{H}_{30} \mathrm{O}_{4}\left(\mathrm{M}+\mathrm{Na}^{+}\right): \mathrm{m} / \mathrm{z}$ 393.2042. Found: $m / z$ 393.2026.

\section{Acknowledgements}

This work was supported by the National Science Foundation (CHE0848870) and NSF instrumentation grants (CHE-0521323). Highresolution mass spectra were obtained at the University of NebraskaCenter for Mass Spectrometry and the COSMIC lab at Old Dominion University. The authors thank Anobick Sar for obtaining IR spectra.

\section{Notes and references}

1. (a) A. D. Patil, A. J. Freyer, L. Killmer, P. Offen, B. Carte, A. J. Jurewicz and R. K. Johnson, Tetrahedron, 1997, 53, 5047-5060 ;

1. (b) Y. F. Hallock, J. H. Cardellina II and M. R. Boyd, Nat. Prod. Lett., 1998, $11,153-160$.

2. F. Marion, D. E. Williams, B. O. Patrick, L. Hollander, R. Mallon, S. C. Kim, D. M. Roll, L. Feldberg, R. Van Soest and R. J. Andersen, Org. Lett., 2006, 8, 321-324.

3. (a) M. Inoue, A. J. Frontier and S. J. Danishefsky, Angew. Chem., Int. Ed., 2000, 39, 761-764;

Organic and Biomolecular Chemistry, Vol. 9, No. 22 (November 2011): pg. 7742-7747. DOI. This article is @ Royal Society of Chemistry and permission has been granted for this version to appear in e-Publications@Marquette. Royal Society of Chemistry does not grant permission for this article to be further copied/distributed or hosted elsewhere without the express permission from Royal Society of Chemistry. 
NOT THE PUBLISHED VERSION; this is the author's final, peer-reviewed manuscript. The published version may be accessed by following the link in the citation at the bottom of the page.

3. (b) M. Inoue, M. W. Carson, A. J. Frontier and S. J. Danishefsky, J. Am. Chem. Soc., 2001, 123, 1878-1889;

3. (c) C. C. Hughes and D. Trauner, Angew. Chem., Int. Ed., 2002, 41, 15691572 ;

3. (d) C. C. Hughes and D. Trauner, Tetrahedron, 2004, 60, 9675-9686;

3. (e) D. J. Kerr, A. C. Willis and B. L. Flynn, Org. Lett., 2004, 6, 457-460;

3. (f) I. Martinez, P. E. Alford and T. V. Ovaska, Org. Lett., 2005, 7, 11331135;

3. (g) X. Li, R. E. Kyne and T. V. Ovaska, Org. Lett., 2006, 8, 5153-5156;

3. (h) X. Li, R. E. Kyne and T. V. Ovaska, Tetrahedron, 2007, 63, 1899-1906;

3. (i) X. Li and T. V. Ovaska, Org. Lett., 2007, 9, 3837-3840;

3. (j) X. Li, A. E. Keon, J. A. Sullivan and T. V. Ovaska, Org. Lett., 2008, 10, 3287-3290;

3. (k) B. M. Trost, Y. Hu and D. B. Horne, J. Am. Chem. Soc., 2007, 129, 11781-11790;

3. (I) J. P. Olson and H. M. L. Davies, Org. Lett., 2008, 10, 573-576;

3. (m) G. Mehta and N. S. Likhite, Tetrahedron Lett., 2008, 49, 7113-7116;

3. (n) G. Mehta and N. S. Likhite, Tetrahedron Lett., 2009, 50, 5263-5266;

3. (o) T. V. Ovaska, J. A. Sullivan, S. I. Ovaska, J. B. Winegrad and J. D. Fair, Org. Lett., 2009, 11, 2715-2718;

3. (p) K.-S. Masters and B. L. Flynn, Org. Biomol. Chem., 2010, 8, 12901292;

3. (q) D. Garayalde, K. Krueger and C. Nevado, Angew. Chem., Int. Ed., 2011, 50, 911-915.

4. (a) G. Mehta, N. S. Likhite and C. S. A. Kumar, Tetrahedron Lett., 2009, 50, 5260-5262;

Organic and Biomolecular Chemistry, Vol. 9, No. 22 (November 2011): pg. 7742-7747. DOI. This article is @ Royal Society of Chemistry and permission has been granted for this version to appear in e-Publications@Marquette. Royal Society of Chemistry does not grant permission for this article to be further copied/distributed or hosted elsewhere without the express permission from Royal Society of Chemistry. 
NOT THE PUBLISHED VERSION; this is the author's final, peer-reviewed manuscript. The published version may be accessed by following the link in the citation at the bottom of the page.

4. (b) J. H. George, J. E. Baldwin and R. M. Adlington, Org. Lett., 2010, 12, 2394-2397;

4. (c) E. Alverez-Manzaneda, R. Chahboun, E. Alverez, M. J. Cano, A. Haidour and R. Alvarez-Manzaneda, Org. Lett., 2010, 12, 4450-4453;

4. (d) A. R. Pereira, W. K. Strangman, F. Marion, L. Feldberg, D. Roll, R. Mallon, I. Hollander and R. J. Andersen, J. Med. Chem., 2010, 53, 8523-8533;

4. (e) Y. Zhang, E. Z. Oblak, E. S. D. Bolstad, A. C. Anderson, J. P. Jasinski, R. J. Butcher and D. L. Wright, Tetrahedron Lett., 2010, 51, 61206122.

5. (a) N. J. Wallock and W. A. Donaldson, Org. Lett., 2005, 7, 2047-2049;

5. (b) N. J. Wallock, D. W. Bennett, T. A. Siddiquee, D. T. Haworth and W. A. Donaldson, Synthesis, 2006, 3639-3646;

5. (c) R. K. Pandey, L. Wang, N. J. Wallock, S. Lindeman and W. A. Donaldson, J. Org. Chem., 2008, 73, 7236-7245;

5. (d) J. R. Gone, N. J. Wallock, S. Lindeman and W. A. Donaldson, Tetrahedron Lett., 2009, 50, 1023-1025.

6. S. Chaudhury, W. A. Donaldson, D. W. Bennett, D. T. Haworth, T. A. Siddiquee and J. M. Kloss, J. Organomet. Chem., 2004, 689, 14371443.

7. B. Jousseaume, N. Noiret, M. Pereyre, J.-M. Frances and M. Petraud, Organometallics, 1992, 11, 3910-3914.

8. C. Tao and W. A. Donaldson, J. Org. Chem., 1993, 58, 2134-2143.

9. P. J. Kropp, S. A. McNeely and R. D. Davis, J. Am. Chem. Soc., 1983, 105, 6907-6915.

10. R. A. Gossage, J. T. B. H. Jastrzebski and G. van Koten, Angew. Chem., Int. Ed., 2005, 44, 1448-1454.

\section{Footnotes}

+ Electronic supplementary information (ESI) available: Copies of ${ }^{1} \mathrm{H}$ and ${ }^{13} \mathrm{C}$ NMR spectra of new compounds and ORTEPs for 10, 11, 15 and 16a. CCDC

Organic and Biomolecular Chemistry, Vol. 9, No. 22 (November 2011): pg. 7742-7747. DOI. This article is @ Royal Society of Chemistry and permission has been granted for this version to appear in e-Publications@Marquette. Royal Society of Chemistry does not grant permission for this article to be further copied/distributed or hosted elsewhere without the express permission from Royal Society of Chemistry. 
NOT THE PUBLISHED VERSION; this is the author's final, peer-reviewed manuscript. The published version may be accessed by following the link in the citation at the bottom of the page.

reference numbers 823811-823815. For ESI and crystallographic data in CIF or other electronic format see DOI: $10.1039 / \mathrm{c} 1 \mathrm{ob} 05720 \mathrm{k}$

\# The cif files for 10, 11, 15, 16a and $\mathbf{1 6} \mathbf{b}$ have been deposited with the CCDC. 10: CCDC \# 823813; 11: CCDC \# 823815; 15: CCDC \# 823811; 16a: CCDC \# 823812; 16b: CCDC \# 823814. Crystal structure data for compound ( \pm -16b: $\mathrm{C}_{26} \mathrm{H}_{30} \mathrm{O}_{7} \mathrm{Fe} ; \mathrm{M}=510.35 ;$ triclinic, $\mathrm{P} \overline{\mathrm{l}} ; \mathrm{a}=10.2155(4), \mathrm{b}$ $=10.6315(4), c=13.0110(5) \AA, a=102.007(3)^{\circ}, \beta=106.062(3)^{\circ}, Y=$ $110.218(3)^{\circ} ; U=1199.83(8) \AA^{3} ; T=100 \mathrm{~K} ; Z=2 ; 18938$ reflections measured, 5984 unique $\left(R_{\text {int }}=0.0366\right)$. The final $w R^{2}$ was 0.1155 (all data).

Organic and Biomolecular Chemistry, Vol. 9, No. 22 (November 2011): pg. 7742-7747. DOI. This article is @ Royal Society of Chemistry and permission has been granted for this version to appear in e-Publications@Marquette. Royal Society of Chemistry does not grant permission for this article to be further copied/distributed or hosted elsewhere without the express permission from Royal Society of Chemistry. 